\title{
Hunger and Reduced Self-Control in the Laboratory and across the World: Reducing Hunger as a Self-Control Panacea
}

\author{
Matthew T. Gailliot \\ Psychology Department, Stephen F. Austin State University, Nacogdoches, USA \\ Email: mgailliot@gmail.com
}

Received August $23^{\text {rd }}, 2012$; revised October $16^{\text {th }}, 2012$; accepted November $10^{\text {th }}, 2012$

\begin{abstract}
Ten studies link hunger to reduced self-control. Higher levels of hunger - as assessed by self-report, time since last eating, or physiology — predicted reduced self-control, as indicated by increased racial prejudice, (hypothetical) sexual infidelity, passivity, accessibility of death thoughts and perceptions of task difficulty, as well as impaired Stroop performance and decreased self-monitoring. Increased rates of hunger across 200 countries predicted increased war killings, suggestive of reduced aggressive restraint. In a final experiment, self-reported hunger mediated the effect of hungry ( $\mathrm{v}$ fed) participants performing worse on the Stroop task, suggesting a causal relationship of hunger reducing self-control.
\end{abstract}

Keywords: Self-Control; Self-Regulation; Hunger; Glucose; Executive Functioning

\section{Introduction}

Hunger may be a serious problem. Hunger has been reported to afflict one billion people - nearly one-sixth of the world population (Food and Agricultural Organization, 2009). A person dies from starvation every second, a child every five seconds - accounting for nearly $60 \%$ of all deaths (Food and Agriculture Organization, Economic and Social Department, 2005). The current work examined whether hunger might have a deleterious effect on human psychology-namely, on self-control. Hunger occurs both temporarily and chronically, and both may hamper good self-control.

Self-control is important. Good self-control contributes to many benefits throughout the lifespan, including better social relationships, mental health, and intellect, and less criminality (Finkel \& Campbell, 2001; Gottfredson \& Hirschi, 1990; Shoda, Mischel, \& Peake, 1990; Tangney, Baumeister, \& Boone, 2004). Self-control may have evolved on the basis of its fostering social cooperation and harmony (Baumeister, 2005). Poor self-control thus contributes to many ills both individually and societally. Hunger therefore could thwart many desirable outcomes both occasionally and chronically.

Humans are metabolic entities. One of our most important capacities - self-control - is metabolically expensive yet requires having adequate metabolic energy (Gailliot \& Baumeister, 2007a; Gailliot et al., 2007). One supporting idea is that hunger is a state in which reductions in energy availability preclude optimal self-control.

Ten studies link hunger to reduced self-control. This conclusion is strengthened in that a variety of indicators were used to assess indices of both hunger (self-reported hunger, time since last eating, physiology, societal hunger) and self-control (Stroop performance, sexual behavior, aggression, prejudice, death-thought accessibility, passivity, self-monitoring, perceptions of task difficulty). The work includes data from the laboratory, the field, and across large populations, incorporating both correlational and experimental methods.

\section{Harmful Effects Hunger-Might Hunger Impair Self-Control?}

Both temporary and chronic hungers have many harmful psychological effects. Hunger worsens mental health, increases interpersonal conflict, harms many cognitive abilities (e.g., verbal fluency, memory, learning, intelligence), and increases absenteeism, tardiness, discipline problems, and nurse visits among schoolchildren (Alaimo, Olson, Edward, \& Frongillo, 2001; Barrett, Radke-Yarrow, \& Klein, 1982; Howard, 2008; Lopez-Sobaler, Ortega, Quintas, Navia, \& Requejo, 2003; Murphy, 2007). Self-control has been linked to the same, and similar, abilities, such as intelligence, attention control, and memory (Duckworth \& Seligman, 2005; Schmeichel, 2007; Schmeichel, Vohs, \& Baumeister, 2003; Tangney, Baumeister, \& Boone, 2004). One especially relevant study found that increased food insecurity predicted worse self-control among schoolchildren, as assessed by teacher ratings (Howard, 2008). This suggests that hunger might harm self-control generally.

Research on glucose provides one basis to suggest an influence of hunger on self-control. Low blood-glucose occurs during hunger (Campfield \& Smith, 1986; Ciampolini et al., 2008; Ciampolini \& Bianchi, 2006; De Graaf, Blom, Smeets, Stafleu, \& Hendriks, 2004; Gavin, 2001; Elliot, Keim, Stern, Teff, \& Havel, 2002; Merimee \& Tyson, 1974) and has been linked to reduced self-control (DeWall, Baumeister, Gailliot, \& Maner, 2008; DeWall, Gailliot, Deckman, \& Bushman, 2009; Fairclough \& Houston, 2004; Gailliot et al., 2007; Gailliot \& Baumeister, 2007a; Gailliot, Peruche, Plant, \& Baumeister, 2009; Masicampo \& Baumeister, 2008). Likewise, cognitive effects of hunger have been linked to low glucose (Benton \& Sargent, 1992; Pollitt, Leibel, \& Greenfield, 1981; Pollitt, Lewis, Garza, \& Schulman, 1982; Pollitt \& Mathews, 1998). It may be unlikely that changes in glucose account entirely for any influence of hunger - that is, that hunger is only a proxy for glucose. A relatively large number of studies have found that impairments caused by hunger are not due to glucose (Pollitt, Cueto, \& Jacoby, 1996; Cueto et al., 1995, unpublished data, as cited 
in Pollitt, 1995).

\section{The Current Work}

Ten studies assessed the relationship between hunger and self-control. Their purpose is to relate hunger to indices of reduced self-control across a variety of domains. The prediction is that increased hunger will accompany reductions in selfcontrol.

Hunger could potentially influence self-control via changes in mood. Being hungry might be aversive and increase negative mood, or it might increase or decrease arousal by making people jittery or tired. Providing a test of these ideas, several of the studies include measures of mood and arousal.

\section{Study 1: Self-Reported Hunger Predicts Stroop Performance}

The hypothesis for Study 1 was that higher self-reported hunger would predict worse performance on the Stroop task, which requires self-control in the form of overriding the automatic tendency to read words and instead to focus on their font color.

\section{Method}

Nineteen undergraduates ( 15 women, 4 men) participated for a course requirement. Participants first reported their current hunger level on a scale from 1 (not at all hungry) to 7 (very hungry). Participants later completed the Brief Mood Introspection Scale (BMIS) as a measure of mood and arousal (Mayer \& Gaschke, 1988). Afterward, they completed the Stroop task. Participants completed 100 trials in which they saw a color word (red, blue, or green) and were asked to state aloud its incongruent font color (red, blue, or green) as quickly and accurately as possible.

\section{Results and Discussion}

Higher self-reported hunger predicted more errors on the Stroop task, $r(19)=.42, p<.05$ (one-tailed), but was unrelated to completion time, ns. The relationship between hunger and errors remained when controlling for mood valence, arousal, and completion time, $r(14)=.49, p=.05$.

\section{Study 2: Physiological Hunger Predicts Stroop Performance}

Rather than relying on a self-report measure of hunger, Study 2 included a physiological measure. Past work indicates that hunger, whether or not consciously perceived, initiates when blood-glucose levels are at or below $81.8 \mathrm{mg} / \mathrm{dL}$ (Ciampolini et al., 2008), or perhaps $87 \mathrm{mg} / \mathrm{dL}$ (Ciampolini \& Bianchi, 2006). Study 2 therefore tested whether self-control would be impaired at or below $81.8 \mathrm{mg} / \mathrm{dL}$ or $87 \mathrm{mg} / \mathrm{dL}$, with the $81.8 \mathrm{mg} / \mathrm{dL}$ measure taking precedence over the $87 \mathrm{mg} / \mathrm{dL}$ measure due to its being better supported (Ciampolini et al., 2008). The work includes assessment of whether the relationship between hunger and self-control was predicted by linear glucose levels so as to separate any influence of glucose from that of hunger. The hypothesis was that activated physiological hunger would predict impaired Stroop performance, and that this relationship would be separated from linear glucose levels. The study in- cludes two separate samples.

\section{Method}

Twenty-nine (19 women, 10 men; sample 1) and forty-two (31 women, 11 men; sample 2) undergraduates participated for a course requirement. Participants first had their glucose levels assessed, using single-use blood sampling lancets and an Accu-chek compact meter. Next, they completed the UWIST Mood Adjective Checklist as a measure of hedonic tone, tensearousal, and energetic-arousal (Matthews, Jones, \& Chamberlain, 1990; sample 1) or BMIS (sample 2) and the Stroop task. Participants in the first sample completed the same Stroop procedure used in Study 1, whereas those in the second sample performed the task for 3 minutes.

\section{Results and Discussion}

Participants in the first sample who scored in the hunger group (i.e., those who had glucose levels at or below 81.8 $\mathrm{mg} / \mathrm{dL})$ made more errors on $(M=3.14, S D=1.47)$ and took longer to complete (in seconds; $M=94.77, S D=12.92$ ) the Stroop than did those in the no-hunger group (for errors, $M=$ $1.82, S D=1.47$; for completion time, $M=72.18, S D=22.90)$, $F(1,27)=4.33, p<.05, d=.90, r=.41$ (for errors), $F(1,27)=$ $16.23, p<.001, d=1.22, r=.52$ (for completion time), when controlling for hedonic tone, tense-arousal, and energeticarousal. Linear glucose levels predicted neither errors nor completion time, $p \mathrm{~s}>.17$.

Among participants in the second sample, hunger was defined by glucose levels at or below $87 \mathrm{mg} / \mathrm{dL}$ because the sample was too small to use the $81 \mathrm{mg} / \mathrm{dL}$ criterion. Participants in the hungry group completed fewer trials $(M=204.71, S D=$ $41.59)$ than did those in the nonhungry group $(M=233.94, S D$ $=41.57$ ) $, F(1,39)=2.87, p<.05, d=-.70, r=-.33$ (onetailed), when controlling for mood valence, arousal, and errors on the Stroop (the two groups did not differ in errors, $p=.26$ ). Linear glucose levels did not predict completion time, $p=.62$. These results indicate that the presence or absence of hunger is related to self-control. It is unclear why hunger would relate inconsistently to either speed or accuracy, though one explanation is that, lacking self-control, participants may trade off one capacity for the other, and that hungry participants devoted themselves more to accuracy.

That the Stroop task measures domain general self-control raises the hypothesis tested in the subsequent studies, namely that hunger is associated with impaired self-control across multiple domains.

\section{Study 3: Self-Reported Hunger Predicts Sexual Infidelity}

People sometimes control their sexual thoughts and behavior, which requires self-control (Barth \& Kinder, 1987; Carnes, 1983; Coleman, 1992; Earle \& Crow, 1990; Gold \& Heffner, 1998; Wiederman, 2004). Reduced self-control is associated with increased sexuality (Armentrout \& Hauer, 1978; Exner, Meyer-Bahlburg, Ehrhardt, 1992; Giotakos, Vaidakis, Markianos, \& Chrisodoulou, 2003; Hanson \& Bussiere, 1998; Hernandez \& DiClemente, 1992; Kalichman et al., 1994; Koepp, Schildbach, Schmager, \& Rohner, 1993; McGrath, 1991; Wills, Gibbons, Gerrard, Murry, \& Brody, 2003; Zanarini et al., 1998; 
Gailliot \& Baumeister, 2007b).

The hypothesis for Study 3 was that higher self-reported hunger would predict an increased likelihood of sexual infidelity, indicating reduced self-control. The idea is that people in committed romantic relationships sometimes desire to engage in sexual acts outside of their relationship but that they use self-control to avoid doing so.

\section{Method}

Forty undergraduates (32 women, 8 men) participated for a course requirement. Participants first reported their current hunger level. Next, they completed the UWIST Mood Adjective Checklist. Participants later responded to two hypothetical scenarios in which they were to imagine being in a committed romantic relationship and to indicate their likelihood of kissing or having sex with a person other than their partner, using a scale from 1 (not at all likely) to 9 (very likely). Last, participants completed 14 items from the Marlowe-Crowne Social Desirability Scale (Crowne \& Marlowe, 1960).

\section{Results and Discussion}

Higher self-reported hunger predicted an increased likelihood of sexual infidelity across the two scenarios, $r(40)=.40, p$ $<.05$. The relationship remained when controlling for hedonic tone, tense-arousal, energetic-arousal, and social desirability scores, $r(34)=.33, p=.05$.

\section{Study 4: Societal Hunger Predicts War Killings}

Poor self-control and factors that undermine self-control (i.e., metabolic problems) increase aggressive thought and behavior (DeWall et al., 2007; Gailliot \& Baumeister, 2007a; Stucke \& Baumeister, 2006). Likewise, some evidence links hunger to aggression (Gray, 1986; Howard, 2008; Kleinman et al., 1998; Murphy, Wehler et al., 1998; Reid, 2000). The hypothesis was that hunger levels, among both children and adults, would predict war killings across 200 countries, which may potentially arise from reductions in the self-control of aggressive restraint.

\section{Method}

Data used included rates of undernourishment in 2000 (United Nations, 2004) and of children enrolled in primary and secondary education in 2002 (United Nations, 2004), estimations of the number of people killed in war in 2002 (World Health Organization, 2004), the human poverty indices for 2002 (United Nations, 2004), and gross national product for 2002 (United Nations, 2004) across 200 countries.

\section{Results and Discussion}

Greater undernourishment predicted increased war killings, $r(200)=.37, p<.001$. Undernourishment predicted war killings when controlling for enrollment in primary and secondary education, poverty, and gross national product $(b=3.07), t(1,194)$ $=3.79, p<.001$. Thus, the more hunger was common to a country, the more likely war killings were in that country.

One limitation is that the hunger data were from two years prior to the other data, though hunger tends to be temporally stable (e.g., undernourishment rates for 1990 and 2000 correlate highly, $r(200)=.81, p<.001$, despite the 10 -year time span).
One alternative possibility is that the targets of the killing or other people experienced hunger, rather than the actor.

\section{Study 5: Self-Reported Hunger Predicts Prejudice}

Hunger relates to negativity toward others in the form of killing, perhaps too for prejudice and bias. Stereotypes and prejudice arise automatically, and so self-control allows one to avoid their salience and influence (Devine, 1989). Several studies are consistent with the idea that impaired self-control increases prejudice (Gailliot, Plant, Butz, \& Baumeister, 2007; Gordijn, Hindriks, Koomen, Dijksterhuis, \& Van Knippenberg, 2004; Govorun \& Payne 2006; Inzlicht et al., 2006; Johns, Inzlicht, \& Schmader, 2008; Ketterman, 2004; Muraven, 2008; Richeson, Trawalter, \& Shelton, 2005). The hypothesis for Study 5 was that higher self-reported hunger would predict higher prejudice, indicative of reduced self-control.

\section{Method}

Ninety-four undergraduates (71 women, 23 men) participated for a course requirement. Participants first reported their current hunger level. They later completed the 14-item measure of social desirability and UWIST Mood Adjective Checklist.

Afterward, participants read two descriptions of crimes that had been committed and viewed images of a Black and White suspect. Participants indicated the extent to which they perceived each suspect as being hostile, aggressive, dangerous, and reckless (negative traits), as well as intelligent, careful, sensitive, and responsible (positive traits) on a scale from 1 (not at all) to 9 (a lot).

\section{Results and Discussion}

Greater self-reported hunger predicted less positive trait ratings for the Black, $r(94)=-.17, p<.05$ (one-tailed), but not White, $r(94)=-.10, p=.35$, suspect. This links hunger to prejudice. Hunger was unrelated to negative trait ratings for either the White or Black suspect, $p s>$.6. The relationship between hunger and positive trait ratings for the Black suspect was significant, or marginally significant, when controlling for either hedonic tone, tense-arousal, energetic arousal, or social desirability, $r \mathrm{~s}<-.16, \mathrm{ps}<.06$ (one-tailed).

\section{Study 6: Time Since Last Eating Predicts Death Thought Accessibility}

Another domain relevant to self-control is the accessibility of thoughts related to death. A variety of stimuli and situations activate thoughts related to death. When death thoughts arise, people may use self-control to suppress them or to think about something else (Arndt, Greenberg, Solomon, Pyszczynski, \& Simon, 1997; Gailliot, Schmeichel, \& Baumeister, 2006; Pollak, 1979, 1980; Pyszczynski, Greenberg, \& Solomon, 1999). The hypothesis was that more time since last having eaten-suggesting increased hunger-would predict reduced self-control in the form of increased death thought accessibility.

\section{Method}

Fifty-four undergraduates (39 women, 15 men) participated for a course requirement. Participants first estimated the amount 
of time since they had last eaten. They next completed the 14item measure of social desirability and the UWIST Mood Adjective Checklist. They later were given 6 word fragments (e.g., SK_LL) that could be completed with a word either related (e.g., SKULL) or unrelated (e.g., SKILL) to death.

\section{Results and Discussion}

Recalling more time since last having eaten predicted including more death-related words in one's responses, $r(54)$ $=.35, p<.05$, suggesting increased death-thought accessibility and the reduced self-controlled suppression thereof. This relationship remained when controlling for hedonic tone, tensearousal, energetic-arousal, and social desirability scores, $r(48)$ $=.32, p<.05$.

\section{Study 7: Self-Reported Hunger Predicts Passivity}

There is high overlap between impaired self-control and increased passivity (Baumeister, Bratslavsky, Muraven, \& Tice, 1998; Vohs \& Gailliot, 2006). The link may be that both are caused by lacking energy needed for effortful thought and behavior. Hunger has been linked to passivity, such as to increased television watching and reductions in initiating social contact, being physically active, and exerting less effort at school (Alaimo et al., 2001; Chavez \& Martinez, 1979; Pollitt, Golub, \& Gorman, 1996; Sigman et al., 2005). The hypothesis was that higher self-reported hunger would predict greater passivity, suggesting reduced self-control.

\section{Method}

One-hundred sixty-two people walking through a subway terminal in Amsterdam, Holland participated on a voluntary basis. As participants approached the terminal exit, a research assistant asked whether they had eaten breakfast and recorded whether participants exited via the escalator (the passive option) or the adjacent stairs.

\section{Results and Discussion}

A chi-square analysis indicated that participants who had not eaten breakfast were more likely to use the escalator than the stairs, whereas participants who had eaten breakfast were more likely to use the stairs than the escalator, $\chi^{2}=2.89, p<.05$ (one-tailed; see Figure 1). Hunger may be linked to increased passivity (using the stairs) because energy is low during hunger and passivity helps conserve energy (see Muraven \& Slessareva, 2003; Muraven et al., 2006).

\section{Study 8: Physiological Hunger Predicts Passivity}

Whereas Study 7 linked passivity to self-reported hunger, Study 8 assessed the relationship of passivity and tendencies toward physiological hunger on a standardized examination-a glucose tolerance test (i.e., an assessment of blood-glucose levels after a 9-hour fast at night and ingestion of a glucose drink in the morning). The prediction was that a greater likelyhood of hunger (using the criterion used in Study 2) would predict increased passivity during the past month in the form of less physical activity.

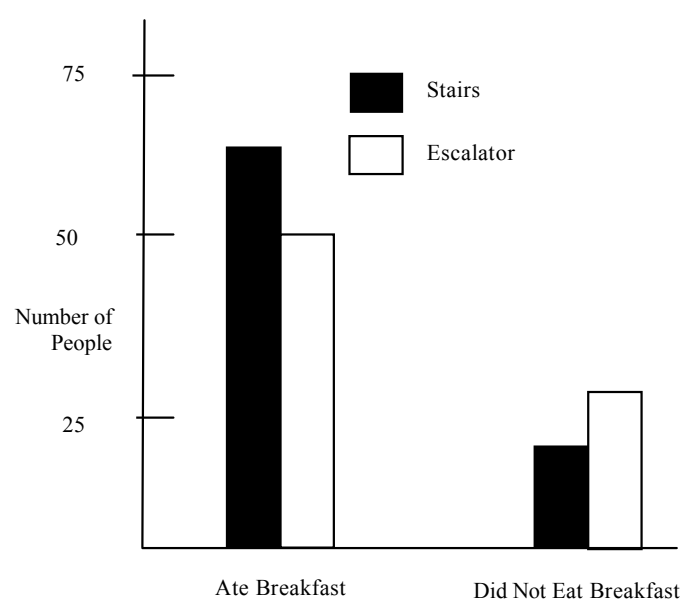

Figure 1.

Number of people who used the stairs or escalator as a function of having eaten breakfast (Study 7).

\section{Method}

Data were from the Third National Health and Nutrition Examination Survey (NHANES III) 1988-1994 from the National Center for Health Statistics. It included 2945 participants (1475 women, 1475 men). Participants completed a glucose tolerance test. They also reported the number of times they had walked or bicycled during the past 30 days - used as the measure of passivity in the current study. Education level and household and family income levels were obtained.

\section{Results and Discussion}

Participants in the hungry group $(<81.8 \mathrm{mg} / \mathrm{dL})$ reported having walked or bicycled less $(M=1.60, S D=.50)$ than did those in the non-hungry group $(M=1.70, S D=.51), F(1,2945)$ $=11.67, p=.001, d=-.20, r=-.10$, controlling for education and income levels. Increased tendencies to experience hunger during a glucose tolerance test therefore predicted greater passivity during the prior month.

Linear glucose levels predicted the extent of walking and bicycling, $r(2950)=.11, p<.001$, though both glucose level and hunger group predicted walking and bicycling when simultaneously included in a regression model. In this case, both hunger and linear glucose levels might contribute to passivity, if the relationships are causal.

Of note, other data from NHANES III that allows the test of related hypotheses using different data may support null or contrary conclusions. A more nuanced understanding may be more accurate.

\section{Study 9: Self-Reported Hunger Predicts Self-Monitoring and Perceived Task Difficulty}

Study 9 tested the hypotheses that greater hunger would predict two other factors related to reduced self-control-perceptions of task difficulty and self-monitoring. Good self-monitoring - paying attention to the self, such as to meet standards for thought and behavior - is coupled with good self-control (Baumeister, Heatherton, \& Tice, 1994). If hunger relates negatively to self-control, then it might relate to reduced monitoring.

When energy is low or capacity is reduced, perceptual biases 
can emerge such that tasks seem more effortful (Bhalla \& Proffitt, 1999; McCloskey, Ebeling, \& Goodwin, 1974; Proffitt, Stefanucci, Banton, \& Epstein, 2003). To the extent that hunger is associated with low energy availability for tasks or reduced self-control capacity, then hunger might be associated with stronger perceptions of the extent to which a given task requires effort.

\section{Method}

Twenty-two undergraduates (15 women, 7 men) participated for extra credit toward a course grade. Participants first watched a boring, 6-minute video (without sound) of a woman talking. At its end, they were asked to indicate how difficult it was to watch the video, using a scale from 1 (not at all) to 7 (very). Next, participants completed the BMIS as a measure of mood and arousal.

Participants later completed a task in which they were given star-shaped stickers and asked to use them to create a pattern on a sheet of paper. Participants later were asked to recall the number of stickers they had used (a measure of self-monitoring) and to indicate the extent to which they had been paying attention to the number of stickers they used, using a scale from 1 (not at all) to 7 (very much).

\section{Results and Discussion}

Greater self-reported hunger predicted increased perceptions of task difficulty, $r(22)=.38, p<.05$ (one-tailed). Greater hunger also predicted larger underestimations of the number of stickers one used relative to the number of stickers one recalled having used (reduced self-monitoring), $r(22)=-.36, p<.05$ (one-tailed). Good self-monitoring improves self-control, and so it is possible that hunger relates to self-control via changes in self-monitoring.

Hunger was unrelated to reports of having paid attention to the numbers of stickers one had used, $p>.77$. This indicates that hunger was related to reduced self-monitoring and that participants were unaware of any reductions in self-monitoring. Hunger was not related to mood valence or arousal, $p \mathrm{~s}>.15$.

\section{Study 10: Hunger Impairs and Food Improves Stroop Performance}

Studies 1-9 present correlational evidence linking hunger to self-control, yet experimental evidence is required to draw any causal conclusion. The final study manipulated and measured hunger in an experiment designed to assess for causal evidence that hunger impairs self-control, relative to eating restoring it.

\section{Method}

Twenty-five undergraduates (18 women, 7 men) participated for a course requirement and were instructed to arrive hungry without having eaten beforehand. As part of a different experimental test, they first watched a 6-minute video (without sound) of a woman talking with words appearing in the corner of the screen. Participants were asked to use self-control by avoiding looking at the words instead to focus on the woman's face. Afterwards, participants randomly assigned to the fed condition ate a muffin breakfast bar, whereas those in the hunger condition did not receive food. Participants then completed the BMIS and indicated their current hunger level in an embedded item.
Last, participants completed the Stroop task (using the same procedure that was used among the second sample of participants in Study 2).

\section{Results and Discussion}

Participants in the hungry condition made more errors on the Stroop task $(M=14.48, S D=14.86)$ than did those in the fed condition $(M=3.44, S D=14.86), F(1,19)=3.13, p<.05, d$ $=.74, r=.35$ (one-tailed), when controlling for mood valence, arousal, and completion time on the Stroop. The difference in completion time between conditions was nonsignificant, $p=.98$. Hunger thus impaired self-control performance.

Hungry participants indicated being more hungry $(M=3.08$, $S D=1.73)$ than did fed participants $(M=1.46, S D=.78), F(1$, $23)=9.40, p=.005, d=1.21, r=.52$. Hungry and fed participants did not differ in Stroop errors when controlling for hunger levels, $p=.18$. Likewise, a Goodman (1960) test of mediation indicated that self-reported hunger mediated the effect of food (v hunger) on Stroop errors, $z=3.61, p<.001$. These results show direction and causality. Hunger impairs self-control. Eating improves it.

\section{General Discussion}

Across 10 studies, hunger-assessed using multiple measures-was linked to reduced self-control, as suggested by increased sexual behavior, aggression, prejudice, death-thought accessibility, passivity, and perceptions of task difficulty, as well as impaired Stroop performance and reduced self-monitoring. Hunger is therefore linked to many important outcomes, including war killings across the world. A final study demonstrated causality.

Aside from the three studies that used the Stroop-which clearly require self-control-much of the work rests on the assumption that self-control was involved in the observed phenomena. The individuals may have experienced little self-control conflict over their sexual, aggressive, or prejudicial behaveior, for example. Another assumption is the direction of the relationship between hunger and self-control. For example, though hunger may cause killing, so too may killing cause hunger (Nafziger \& Auvinen, 2002), such as among warriors cutoff from the food supply following attack. Or, other variables may account for the relationship - individuals prone to skip meals, for example, may be more likely to demonstrate hunger and reduced self-control. Thoughts of death may arise with hunger because of increased cultural factors or increased accessibility of negative constructs (e.g., increased salience of phrases such as, "dying from hunger" or "I am starving").

Though hunger was defined in various ways, the work did not assess for mediation ( $c f$. potential mediation by self-monitoring and task difficulty, Study 9). Hormones, such as leptin or grehlin (Malik, McGlone, Bedrossian, \& Dagher, 2008; OMIM, 2009), or multiple sources of metabolite, such as glycogen in the brain or liver (Gailliot, 2008; Gailliot \& Baumeister, 2007a), might be influential. Conservation mechanisms could occur that attenuate effort or resource expenditure (Muraven \& Slessareva, 2003; Muraven, Shmueli, \& Burkley, 2006) during hunger. Other potential mediators include self-control failure providing emotional relief (Tice, Baumeister, Shmueli, \& Muraven, 2007; Tice, Bratslavsky, \& Baumeister, 2001) or escape from the self (Heatherton \& Baumeister, 1991), assuming that hunger is at 
least somewhat aversive or that it might increase self-awareness. The majority of the current studies included measures of mood and arousal, yet little evidence emerged to support their having influence. Self-control might involve increased glucose use in the brain (Richeson et al., 2003), suggesting that hunger's reducing self-control may involve provision or conservation of cerebral glucose (see Messier \& White, 1987). It is unclear whether hunger impairs self-control or reduces its use. Perhaps increased motivation can overcome the effects of hunger (Muraven \& Slessareva, 2003).

Overeating and failures in dieting may be the most common example of impaired self-control because people sacrifice dietary goals so as to maintain self-control energy in other ways. If one must fail at self-control, then it is best to fail at dietary goals so as to uphold other standards.

Hunger may be relevant to the phenomena of self-control use depleting glucose and impairing subsequent self-control (Gailliot \& Baumeister, 2007a; Gailliot et al., 2007). Perhaps glucose depletion activates hunger sensations that function to replenish energy needed for self-control. Indeed, attentional biases to food have been found to occur after self-control use (Gailliot, 2009).

More comprehensive conclusions may be made when making connections among individual studies. Hunger was linked to increased death thoughts (Study 6), prejudice (Study 4), and war killings (Study 4). Hunger could impair self-control so as to increase death thought and prejudice, thereby predisposing toward aggression against outgroups (see Pyszczynski et al., 1999).

Energy for biological and psychological processes is limited, with high activity for one process potentially reducing energy available for others (Gailliot, Hildebrandt, Eckel, \& Baumeister, 2010). To the extent that hunger impairs self-control because of reduced energy availability, then it is plausible that hunger may influence energy-consuming processes other than self-control, such as immune activity or reproduction. A null, or even positive, relationship between hunger and self-control may be accounted for by reductions in other processes, such as good selfcontrol being maintained during times of hunger at the expense of comprised immune functioning.

One conundrum is how people suffering from anorexia (selfstarvation) maintain the self-control to avoid eating. Anorexia is associated with increased dopamine in the brain (Barry \& Klawans, 1976) and opioid activity in cerebrospinal fluid (Kaye, Pickar, Naber, \& Ebert, 1982). Both dopamine and opioids increase positive feelings, which might help to sustain extreme eating restraint despite incurred hunger (see Tice, Baumeister, Shmueli, \& Muraven, 2007).

Self-control is among the most distinctively human and important capacities. Hunger might impair life in both trivial and significant ways - for one billion people chronically and seven billion at least temporarily. Broken promises, hate, and fighting may be the result. The, perhaps hyperbolical, action of ensuring adequate distribution of food across the globe could prove to be a self-control panacea.

\section{REFERENCES}

Alaimo, K., Olson, C. M., Edward, A., \& Frongillo, J. (2001). Food insufficiency and America's school-aged children's cognitive, academic, and psychosocial development. Pediatrics, 108, 44-53.

Armentrout, J. A., \& Hauer, A. L. (1978). MMPIs of rapists of adults, rapists of children, and non-rapist sex offenders. Journal of Clinical Psychology, 34, 330-332.

doi:10.1002/1097-4679(197804)34:2<330::AID-JCLP2270340213> 3.0.CO;2-R

Arndt, J., Greenberg, J., Solomon, S., Pyszczynski, T., \& Simon, L. (1997). Suppression, accessibility of death-related thoughts, and cultural worldview defense: Exploring the psychodynamics of terror management. Journal of Personality and Social Psychology, 73, 5-18. doi:10.1037/0022-3514.73.1.5

Barrett, D. E., Radke-Yarrow, M., \& Klein, R. E. (1982). Chronic malnutrition and childbehavior: Effects of early caloric supplementation on social and emotional functioning at school age. Developmental Psychology, 18, 541-556. doi:10.1037/0012-1649.18.4.541

Barry, V. C., \& Klawans, H. L. (1976). One the role of dopamine in the pathophysiology of anorexia nervosa. Journal of Neural Transmission, 38, 107-122. doi:10.1007/BF01262969

Barth, R. J., \& Kinder, B. N. (1987). The mislabeling of sexual impulsivity. Journal of Sex and Marital Therapy, 13, 15-23. doi:10.1080/00926238708403875

Baumeister, R. F., Bratslavsky, E., Muraven, M., \& Tice, D. M. (1998). Ego depletion: Is the active self a limited resource? Journal of Personality and Social Psychology, 74, 1252-1265. doi: $10.1037 / 0022-3514.74 .5 .1252$

Baumeister, R. F. (2005). The cultural animal: Human nature, meaning, and social life. New York: Oxford University Press.

Baumeister, R. F., Heatherton, T. F., \& Tice, D. M. (1994). Losing control: How and why people fail at self-regulation. San Diego, CA: Academic Press.

Benton, D., \& Sargent, J. (1992). Breakfast blood glucose and memory. Biological Psychology, 33, 207-221. doi:10.1016/0301-0511(92)90032-P

Bhalla, M., \& Proffitt, D. R. (1999). Visual-motor recalibration in geographical slant perception. Journal of Experimental Psychology: Human Perception and Performance, 25, 1076-1096. doi:10.1037/0096-1523.25.4.1076

Campfield, L. A., \& Smith, F. J. (1986). Functional coupling between transient declines in blood glucose and feeding behavior: Temporal relationships. Brain Research Bulletin, 17, 427-433. doi:10.1016/0361-9230(86)90250-9

Carnes, P. (1983). Out of the shadows: Understanding sexual addiction. Minneapolis: CompCare.

Chavez, A., \& Martinez, M. (1979). Consequences of insufficient nutriation on childcharacteristics and behavior. In D. A. Levitsky (Ed.), Malnutrition, environment and behavior (pp. 238-255). Ithaca, NY: Cornell University Press.

Ciampolini, M., \& Bianchi, R. (2006). Training to estimate blood glucose and to formassociations with initial hunger. Nutrition and $\mathrm{Me}$ tabolism, 3, 42. doi:10.1186/1743-7075-3-42

Ciampolini, M., Bianchi, R., de Pont, B., Lovell-Smith, D., Sifone, M., van Weeren, M. et al. (2008). Sustained self-regulation of energy intake: Initial hunger is associated with low pre-meal blood glucose and prevents energy accumulation.

http://win.aegov.com/public/2763_NC\%2012\%20Dic\%2008.doc

Coleman, E. (1992). Is your patient suffering from compulsive sexual behavior? Psychiatric Annals, 22, 320-325.

Crowne, D. P., \& Marlowe, D. (1960). A new scale of social desirability independent of psychopathology. Journal of Consulting Psychology, 24, 349-354. doi:10.1037/h0047358

De Graaf, C., Blom, W. A. M., Smeets, P. A. M., Stafleu, A., \& Hendriks, H. F. J. (2004). Biomarkers of satiation and satiety. American Journal of Clinical Nutrition, 79, 946-961.

Devine, P. G. (1989). Stereotypes and prejudice: Their automatic and controlled components. Journal of Personality and Social Psychology, 56, 5-18. doi:10.1037/0022-3514.56.1.5

DeWall, C. N., Baumeister, R. F., Gailliot, M. T., \& Maner, J. K. (2008). Depletion makes the heart grow less helpful: Helping as a function of self-regulatory energy and genetic relatedness. Personality and Social Psychology Bulletin, 34, 1653-1662. doi: $10.1177 / 0146167208323981$

DeWall, C. N., Baumeister, R. F., Stillman, T. F., \& Gailliot, M. T. (2007). Violence restrained: Effects of self-regulation and its deple- 
tion on aggression. Journal of Experimental Social Psychology, 43, 62-76. doi:10.1016/j.jesp.2005.12.005

DeWall, C. N., Gailliot, M. T., Deckman, T., \& Bushman, B. J. (2009). Sweetened blood cools hot tempers: Physiological self-control and aggression. Aggressive Behavior, 37, 73-78. doi:10.1002/ab.20366

Duckworth, A. L., \& Seligman, M. E. P. (2005). Self-discipline outdoes IQ in predicting academic performance of adolescents. Psychological Science, 16, 939-944. doi:10.1111/j.1467-9280.2005.01641.x

Earle, R. H., \& Crow, G. M. (1990). Sexual addiction: Understanding the phenomenon. Contemporary Family Therapy, 12, 89-104. doi:10.1007/BF00892488

Exner, T. M., Meyer-Bahlburg, H. F. L., \& Ehrhardt, A. A. (1992). Sexual self-control as a mediator of high risk sexual behavior in a New York City cohort of HIV+ and HIV- gay men. Journal of Sex Research, 29, 389-406. doi:10.1080/00224499209551655

Fairclough, S. H., \& Houston, K. (2004). A metabolic measure of mental effort. Biological Psychology, 66, 177-119. doi:10.1016/j.biopsycho.2003.10.001

Finkel, E. J., \& Campbell, W. K. (2001). Self-control and accommodation in close relationships: An interdependence analysis. Journal of Personality and Social Psychology, 81, 263-277.

doi:10.1037/0022-3514.81.2.263

Food and Agriculture Organization (2009). The state of food insecurity in the world 2009: Economic crises-impacts and lessons learned. Food and Agriculture Organization of the United Nations.

Food and Agriculture Organization of the United Nations Economic and Social Department (2005). The state of food insecurity in the world 2005: Eradicating world hunger-Key to achieving the millennium development goals. Food and Agriculture Organization of the United Nations.

Gailliot, M. T. (2009). Having used self-control increases attention to food: A functional bias in the management of metabolic energy and a bias toward indulgence. Unpublished manuscript.

Gailliot, M. T., Peruche, B. M., Plant., E. A., \& Baumeister, R. F. (2009). Stereotypes and prejudice in the blood: Sucrose drinks reduce prejudice and stereotyping. Journal of Experimental Social Psychology, 45, 288-290. doi:10.1016/j.jesp.2008.09.003

Gailliot, M. T. (2008). Unlocking the energy dynamics of executive functioning: Linkingexecutive functioning to brain glycogen. Perspectives on Psychological Science, 3, 245-263. doi:10.1111/j.1745-6924.2008.00077.x

Gailliot, M. T., \& Baumeister, R. F. (2007a). The physiology of willpower: Linking blood glucose to self-control. Personality and Social Psychology Review, 11, 303-327. doi:10.1177/1088868307303030

Gailliot, M. T., \& Baumeister, R. F. (2007b). Self-regulation and sexual restraint: Dispositionally and temporarily poor self-regulatory abilities contribute to failures at restraining sexual behavior. Personality and Social Psychology Bulletin, 33, 173-186. doi:10.1177/0146167206293472

Gailliot, M. T., Baumeister, R. F., DeWall, C. N., Maner, J. K., Plant, E. A., Tice, D. M., Brewer, L. E., \& Schmeichel, B. J. (2007). Selfcontrol relies on glucose as a limited energy source: Willpower is more than a metaphor. Journal of Personality and Social Psychology, 92, 325-336. doi:10.1037/0022-3514.92.2.325

Gailliot, M. T., Hildebrandt, B., Eckel, L. A., \& Baumeister, R. F. (2010). A theory of limited metabolic energy and premenstrual syndrome (PMS) symptoms-Increased metabolic demands during the luteal phase divert metabolic resources from and impair self-control. Review of General Psychology, 14, 269-282. doi:10.1037/a0018525

Gailliot, M. T., Plant, E. A., Butz, D. A., \& Baumeister, R. F. (2007). Increasing self-regulatory strength can reduce the depleting effect of suppressing stereotypes. Personality and Social Psychology Bulletin, 33, 281-294. doi:10.1177/0146167206296101

Gailliot, M. T., Schmeichel, B. J., \& Baumeister, R. F. (2006). Selfregulatory processes defend against the threat of death: Effects of self-control depletion and trait self-control on thoughts and fears of dying. Journal of Personality and Social Psychology, 91, 49-62. doi:10.1037/0022-3514.91.1.49

Gavin, J. R. (2001). Pathophysiologic mechanisms of postprandial hyperglycemia. American Journal of Cardiology, 88, 4-8. doi:10.1016/S0002-9149(01)01830-6
Giotakos, O., Vaidakis, N., Markianos, M, \& Chrisodoulou, G. N. (2003). Personalitycharacteristics of sexual offenders. Psychiatriki, 14, 189-190.

Gold, S. N., \& Heffner, C. L. (1998). Sexual addiction: Many conceptions, minimal data. Clinical Psychology Review, 18, 367-381. doi:10.1016/S0272-7358(97)00051-2

Goodman, L. A. (1960). On the exact variance of products. Journal of the American Statistical Association, 55, 708-713. doi:10.1080/01621459.1960.10483369

Gordijn, E. H., Hindriks, I., Koomen, W., Dijksterhuis, A., \& Van Knippenberg, A. (2004). Consequences of stereotype suppression and internal suppression motivation: A selfregulation approach. Personality and Social Psychology Bulletin, 30, 212-224. doi: $10.1177 / 0146167203259935$

Gottfredson, M. R., \& Hirschi, T. (1990). A general theory of crime. Stanford, CA: Stanford University Press.

Govorun, O., \& Payne, B. K. (2006). Ego-depletion and prejudice: Separating automatic and controlled components. Social Cognition, 24, 111-136. doi:10.1521/soco.2006.24.2.111

Gray, G. E. (1986). Diet, crime and delinquency: A critique. Nutritional Review, 44, 89-94. doi:10.1111/j.1753-4887.1986.tb07683.x

Hanson, R. K., \& Bussiere, M. T. (1998). Predicting relapse: A metaanalysis of sexual offender recidivism studies. Journal of Consulting and Clinical Psychology, 66, 348-362. doi: 10.1037/0022-006X.66.2.348

Heatherton, T. F., \& Baumeister, R. F. (1991). Binge eating as escape from self-awareness. Psychological Bulletin, 110, 86-108. doi:10.1037/0033-2909.110.1.86

Hernandez, J. T., \& DiClemente, R. J. (1992). Self-control and ego identity development as predictors of unprotected sex in late adolescent males. Journal of Adolescence, 15, 437-447. doi:10.1016/0140-1971(92)90073-E

Howard, L. L. (2008). Does food insecurity at home affect noncognitive performance at school? A longitudinal analysis of elementary student classroom behavior.

http://business.fullerton.edu/Economics/larryhoward/food_insecurity 2008.pdf

Inzlicht, M., McKay, L., \& Aronson, J. (2006). Stigma as ego depletion: How being the target of prejudice affects self-control. Psychological Science, 17, 262-269. doi:10.1111/j.1467-9280.2006.01695.x

Johns, M., Inzlicht, M., \& Schmader, T. (2008). Stereotype threat and executive resourcedepletion: Examining the influence of emotion regulation. Journal of Experimental Psychology: General, 137, 691705. doi:10.1037/a0013834

Kalichman, S. C., Johnson, J. R., Adair, V., Rompa, D., Multhauf, K., \& Kelly, J. A. (1994). Sexual sensation seeking: Scale development and predicting AIDS-risk behavior among homosexually active men. Journal of Personality Assessment, 62, 385-397. doi: $10.1207 / \mathrm{s} 15327752$ jpa6203 1

Kaye, W. H., Pickar, D., Naber, D., \& Ebert, M. H. (1982). Cerebrospinal fluid opioid activity in anorexia nervosa. American Journal of Psychiatry, 139, 643-645.

Ketterman, R. L. (2004). Stereotype suppression effects on self-control of alcohol consumption. Masters Thesis, Tallahassee, FL: Florida State University.

Kleinman, R. E., Murphy, J. M., Little, M., Pagano, M., Wehler, C. A., Regal, K., \& Jellinek, M. S. (1998). Hunger in children in the United States: Potential behavioral and emotional correlates. Pediatrics, 101, 1-6. doi:10.1542/peds.101.1.e3

Kochanska, G., Murray, K. T., \& Harlan, E. T. (2000). Effortful control in early childhood: Continuity and change, antecedents, and implications for social development. Developmental Psychology, 36, 220 232. doi: $10.1037 / 0012-1649.36 .2 .220$

Koepp, W., Schildbach, S., Schmager, C., \& Rohner, R. (1993). Borderline diagnosis andsubstance abuse in female patients with eating disorders. International Journal of Eating Disorders, 14, 107-111. doi:10.1002/1098-108X(199307)14:1<107::AID-EAT2260140114>3. $0 . \mathrm{CO} ; 2-\mathrm{Q}$

Lopez-Sobaler, A. M., Ortega, R. M., Quintas, M. E., Navia, B., \& Requejo, A. M. (2003). Relationship between habitual breakfast and intellectual performance (logical reasoning) in well-nourished scho- 
olchildren of Madrid (Spain). European Journal of Clinical Nutrition, 57, 49-53. doi:10.1038/sj.ejen.1601815

Malik, S., McGlone, F., Bedrossian, D., \& Dagher, A. (2008). Ghrelin modulates brain activity in areas that control appetitive behavior. Cell Metabolism, 7, 400-409. doi:10.1016/j.cmet.2008.03.007

Masicampo, E. J., \& Baumeister, R. F. (2008). Toward a physiology of dual-process reasoning and judgment: Lemonade, willpower, and expensive rule-based analysis. Psychological Science, 19, 255-260. doi:10.1111/j.1467-9280.2008.02077.x

Matthews, G., Jones, D. M., \& Chamberlain, A. G. (1990). Refining the measurement of mood: The UWIST mood adjective checklist. British Journal of Psychology, 81, 17-42.

doi:10.1111/j.2044-8295.1990.tb02343.x

Mayer, J. D., \& Gaschke, Y. N. (1988). The experience and metaexperience of mood. Journal of Personality and Social Psychology, 55, 102-111. doi:10.1037/0022-3514.55.1.102

McCloskey, D. I., Ebeling, P., \& Goodwin, G. M. (1974). Estimation of weights and tensions and apparent involvement of a "sense of effort". Experimental Neurology, 42, 220-232.

doi:10.1016/0014-4886(74)90019-3

McGrath, R. J. (1991). Sex-offender risk assessment and disposition planning: A review of empirical and clinical findings. International Journal of Offender Therapy \& Comparative Criminology, 35, 328335.

Merimee, T. J., \& Tyson, J. E. (1974). Stabilization of plasma glucose during fasting. Normal variations in two separate studies. New England Journal of Medicine, 291, 1275-1278.

doi:10.1056/NEJM197412122912404

Messier, C., \& White, N. M. (1987). Memory improvement by glucose, fructose, and two glucose analogs: A possible effect on peripheral glucose transport. Behavioral and Neural Biology, 48, 104-127. doi:10.1016/S0163-1047(87)90634-0

Muraven, M. (2008). Prejudice as self-control failure. Journal of Applied Social Psychology, 38, 314-333. doi:10.1111/j.1559-1816.2007.00307.x

Muraven, M., \& Slessareva, E. (2003). Mechanisms of self-control failure: Motivation and limited resources. Personality and Social Psychology Bulletin, 29, 894-906. doi: $10.1177 / 0146167203029007008$

Muraven, M., Shmueli, D., \& Burkley, E. (2006). Conserving selfcontrol strength. Journal of Personality and Social Psychology, 91, 524-537. doi:10.1037/0022-3514.91.3.524

Murphy, J. M. (2007). Breakfast and learning: An updated review. Current Nutrition and Food Science, 3, 3-36. doi: $10.2174 / 1573401310703010003$

Murphy, J. M., Wehler, C. A., Pagano, M. E., Little, M., Kleinman, R. F., \& Jellinek, M. S. (1998). Relationship between hunger and psychosocial functioning in low-income American children. Journal of the American Academy of Child and Adolescent Psychiatry, 37, 163170. doi:10.1097/00004583-199802000-00008

Nafziger, E. W., \& Auvinen, J. (2002). Economic development, inequality, war, and stateviolence. World Development, 30, 153-163. doi:10.1016/S0305-750X(01)00108-5

Pollak, J. M. (1979-1980). Correlates of death anxiety: A review of empirical studies. Omega: Journal of Death and Dying, 10, 97-121. doi:10.2190/4KG5-HBH0-NNME-DM58

Pollitt, E. (1995). Does breakfast make a difference in school? Journal of the American Dietetic Association, 95, 1134-1139. doi:10.1016/S0002-8223(95)00306-1

Pollitt, E., \& Mathews, R. (1998). Breakfast and cognition: An integrative summary. American Journal of Clinical Nutrition, 67, 804-813.

Pollitt, E., Cueto, S., \& Jacoby, E. R. (1998). Fasting and cognition in well- and undernourished schoolchildren: A review of three experimental studies. American Journal of Clinical Nutrition, 67, 779-784.

Pollitt, E., Golub, M., \& Gorman, K. (1996). A reconceptualization of the effects ofundernutrition on children's biological, psychosocial, and behavioral development. Social Policy Report, 10, 1-21.

Pollitt, E., Leibel, R. L., \& Greenfield, R. L. (1981). Brief fasting and cognition in children. American Journal of Clinical Nutrition, 34,
1526-1533.

Pollitt, E., Lewis, N., Garza, C., \& Schulman, R. J. (1982). Fasting and cognitive function. Journal of Psychiatry Research, 17, 169-174. doi:10.1016/0022-3956(82)90018-8

Proffitt, D. R., Stefanucci, J., Banton, T., \& Epstein, W. (2003). The role of effort in perceiving distance. Psychological Science, 14, 106112. doi:10.1111/1467-9280.t01-1-01427

Pyszczynski, T., Greenberg, J., \& Solomon, S. (1999). A dual process model of defense against conscious and unconscious death-related thoughts: An extension of terror management theory. Psychological Review, 106, 835-845. doi:10.1037/0033-295X.106.4.835

Reid, L. L. (2000). The consequences of food insecurity for child wellbeing: An analysis of children's school achievement, psychological well-being, and health. JCPR Working Paper \#137, Chicago, IL: Joint Center for Poverty Research, Northwestern University/University of Chicago.

Richeson, J. A., Trawalter, S., \& Shelton, J. N. (2005). African Americans' implicit racial attitudes and the depletion of executive function after interracial interactions. Social Cognition, 23, 336-352. doi: $10.1521 /$ soco.2005.23.4.336

Schmeichel, B. J. (2007). Attention control, memory updating, and emotion regulationtemporarily reduce the capacity for executive control. Journal of Experimental Psychology: General, 136, 241-255. doi:10.1037/0096-3445.136.2.241

Schmeichel, B. J., Vohs, K. D., \& Baumeister, R. F. (2003). Intellectual performance and ego depletion: Role of the self in logical reasoning and other information processing. Journal of Personality and Social Psychology, 85, 33-46. doi:10.1037/0022-3514.85.1.33

Shoda, Y., Mischel, W., \& Peake, P. K. (1990). Predicting adolescent cognitive and self-regulatory competencies from preschool delay of gratification: Identifying diagnostic conditions. Developmental Psychology, 26, 978-986. doi:10.1037/0012-1649.26.6.978

Sigman, M., Whaley, S. E., Neumann, C. G., Bwibo, N., Guthrie, D., Weiss, R. E. et al. (2005). Diet quality affects the playground activities of Kenyan children. Food and Nutrition Bulletin, 26, 202-212.

Stucke, T. S., \& Baumeister, R. F. (2006). Ego depletion and aggressive behavior: Is theinhibition of aggression a limited resource? European Journal of Social Psychology, 36, 1-13. doi:10.1002/ejsp.285

Tangney, J. P., Baumeister, R. F., \& Boone, A. L. (2004). High selfcontrol predicts goodadjustment, less pathology, better grades, and interpersonal success. Journal of Personality, 72, 271-322. doi:10.1111/j.0022-3506.2004.00263.x

Tice, D. M., Baumeister, R. F., Shmueli, D., \& Muraven, M. (2007). Restoring the self: Positive affect helps improve self-regulation following ego depletion. Journal of Experimental Social Psychology, 43, 379-384. doi:10.1016/j.jesp.2006.05.007

Tice, D. M., Bratslavsky, E., \& Baumeister, R. F. (2001). Emotional distress regulation takes precedence over impulse control: If you feel bad, do it! Journal of Personality and Social Psychology, 80, 53-67. doi: $10.1037 / 0022-3514.80 .1 .53$

United Nations (2004). United Nations Development Program's 2004 Human Development Report.

Vohs, K. D., \& Gailliot, M. T. (2006). Using or losing self-control: Antecedents of regulatory strength and regulatory depletion. Paper presented at the Annual Meeting of the Association for Consumer Research, Orlando.

Wiederman, M. W. (2004). Self-control and sexual behavior. In R. F. Baumeister \& K. D. Vohs (Eds.), Handbook of self-regulation: Research, theory, and applications. New York: Guilford Press.

Wills, T. A., Gibbons, F. X., Gerrard, M., Murry, V. M., \& Brody, G. H. (2003). Familycommunication and religiosity related to substance use and sexual behavior in early adolescence: A test for pathways through self-control and prototype perceptions. Psychology of Addictive Behaviors, 17, 312-323. doi:10.1037/0893-164X.17.4.312

Zanarini, M. C., Frankenburg, F. R., Dubo, E. D., Sickel, A. E., Trikha, A., Levin, A., \& Reynolds, V. (1998). Axis I comorbidity of borderline personality disorder. American Journal of Psychiatry, 155, 17331739 . 